average normal output, it will be at once seen that this patient could well deal with $3 \mathrm{oz}$. of steak or its equivalent in other less purin rich meats, and that the intake of flesh meats need not be further restricted. As a matter of fact, some six months later another estimation showed that the tolerance capacity was increased the allowance of flesh meat was accordingly raised, and the intestinal agencies continued adequately to discharge their functions.

It is, of course, a great advantage when these determinations can be made by exact laboratory methods. As such processes, however, are very tedious and entail the use of apparatus not always available, I suggested, in $1901,{ }^{3}$ an instrument-the purinometer-by means of which the rougher clinical estimations could be made. An extended experience with this method of sedimentation has revealed certain drawbacks, but it has also shown that for ordinary purposes sufficient accuracy may be obtained by it. The following figures, additional to those already published, ${ }^{+}$have been kindly supplied to me by independent workers :

TABLE II.

\begin{tabular}{|c|c|c|}
\hline $\begin{array}{c}\text { Total Purin } \\
\text { Nitrogen } \\
\text { (Purinometer). }\end{array}$ & $\begin{array}{c}\text { Uric Acid } \\
\text { Nitrogen } \\
\text { (Hopkins's Method). }\end{array}$ & $\begin{array}{c}\text { Purin Bases } \\
\text { Nitrogen } \\
\text { (Calculated by Difference). }\end{array}$ \\
\hline $\begin{array}{l}0.2164 \\
0.1776 \\
0.1831 \\
0.1716 \\
0.1732\end{array}$ & $\begin{array}{l}0.1735 \\
0.1632 \\
0.1702 \\
0.1531 \\
0.1410\end{array}$ & $\begin{array}{l}0.0429 \\
0.0144 \\
0.0129 \\
0.0185 \\
0.0322\end{array}$ \\
\hline \multicolumn{3}{|c|}{ TABLE III. } \\
\hline $\begin{array}{l}\underset{\text { Purin Nitrogen }}{\text { Purinometer). }} \\
.\end{array}$ & $\begin{array}{l}\text { Uric Acid Nitrogen } \\
\text { (Hopkins's Method) }\end{array}$ & $\begin{array}{l}\text { Purin bases } \\
\text { Nitrogen } \\
\text { (Calculated by } \\
\text { Difference). }\end{array}$ \\
\hline $\begin{array}{l}0.1629 \\
0.1423 \\
0.1319 \\
0.1284 \\
0.1367 \\
0.1673 \\
0.1795 \\
0.1556 \\
0.1496 \\
0.1468 \\
0.1401 \\
0.1903\end{array}$ & $\begin{array}{l}0.1365 \\
0.1095 \\
0.1054 \\
0.1095 \\
0.1140 \\
0.1344 \\
0.1435 \\
0.1293 \\
0.1381 \\
0.0753 \\
0.0812 \\
0.0976\end{array}$ & $\begin{array}{l}0.0264 \\
0.0328 \\
0.0265 \\
0.0189 \\
0.0227 \\
0.0328 \\
0.0360 \\
0.0263 \\
0.0115 \\
0.0715 \\
0.0588 \\
0.0929\end{array}$ \\
\hline
\end{tabular}

These results, which accord with a vast number of similar estimations made by myself, show that the readings yielded by the purinometer fairly approximate to those obtained by Hopkins's method.

Rilalowski, however, in a St. Petersburg dissertation submitted in 1904, records a series of results obtained by the purinometer, by Hopkins's and by Salkowski's methods, and considers that the purinometer is only suitable for coarse estimations, since it yields an error of from -50 to +50 per cent. (For the interpretation of the Russian text I am indebted to Docent Dr. B. Slowtzoff, st. Petersburg.) Rilalowski also mentions several disadvantages, all of which were anticipated and allowed for when the instrument was graduated, and were included in the original description of it. He proposes to modify the instrument by substituting for the two-chambered tube a single graduated measure, in to which the phosphatefreed urine is placed for treatment with the silver solution. No values for his new graduations are appended. The purinometer was originally designed in order to obviate the use of two separate tubes and the necessary filtering, etc.

Rilalowski relies chiefly upon the following figures (see Table IV), taken from his Table III.

In this table the purinometer is compared with Salkowski's method for uric acid, Hopkins's method being used to control the estimations by Salkowski's method. For absolute comparison, Rilalowski determines the purin bases by Salkowski's method, and adds together the quantities of uric acid and purin bases in order to arrive at the total purin bodies.

If for a moment we leave the purinometer out of the question we may note the experiences of Rilalowski with the methods of Salkowski and Hopkins. In a few instances the results obtained are very similar, but in

\begin{tabular}{|c|c|c|c|}
\hline \multicolumn{3}{|c|}{ TABLE IV. } \\
$\begin{array}{c}\text { Total Purins } \\
\text { (Purinometer). }\end{array}$ & $\begin{array}{c}\text { Uric Acid } \\
\text { (Salkowski). }\end{array}$ & $\begin{array}{c}\text { Uric Acid } \\
\text { (Hopkins). }\end{array}$ & $\begin{array}{c}\text { Percentage Difference } \\
\text { between Hopkins } \\
\text { and Salkowski. }\end{array}$ \\
\hline & & & \\
\hline 0.2340 & 0.1480 & 0.1480 & \\
0.1112 & 0.1425 & 0.1472 & +3.5 \\
0.0802 & 0.1426 & 0.1446 & +1.4 \\
0.0661 & 0.2974 & 0.3075 & +3.4 \\
0.5382 & 0.3066 & 0.3143 & +2.3 \\
0.2231 & 0.0920 & 0.0613 & -33.0 \\
0.0720 & 0.0920 & 0.1680 & +82.0 \\
0.2004 & 0.1026 & 0.2030 & +96.0 \\
0.1125 & 0.1268 & 0.1066 & -16.0 \\
0.2340 & 0.1266 & 0.1840 & +45.0 \\
0.1170 & 0.0590 & 0.1263 & +11.0 \\
0.1248 & 0.0746 & 0.1083 & +45.0 \\
0.0546 & 0.2304 & 0.3056 & +32.0 \\
0.1365 & 0.2634 & 0.1926 & -36.0 \\
0.1768 & 0.2881 & 0.3380 & +17.0 \\
& & &
\end{tabular}

others the figures represent differences of -33 to +96.8 per cent. Yet these two methods are usually recognized as the best available methods for the estimation of urinary uric acid, and in skilled hands they yield almost identical results. If the findings of the purinometer are judged by the estimations of uric acid or of the total purins obtained with Salkowski's processes, the method of Hopkins is made to appear far less reliable than that used for the purinometer. On the other hand, if we accept the figures obtained with Hopkins's method, then Salkowski's are equally at fault.

It may be conceded that the principle of sedimentation from urine is not capable of yielding absolutely accurate results. The density and constitution of pathological urines are constantly changing, thus tending to alter the rate and extent of precipitation. By sedimentation it is not to be expected that results can be obtained that shall be comparable with those afforded by the usual laboratory methods. But although the changed conditions may be marked in different urines, they are more or less constant in individual cases, so that the principle of sedimentation permits relative, if not actual, estimations to be made with sufficient accuracy for clinical purposes.

If the following precautions are taken, the user of the instrument will obtain information sufficiently indicative for the prescription of purin-rich or purin-free dietaries.

The talc used in making up the solutions must be finely ground pure tale and not " prepared French chalk."

After adding each solution the apparatus should be vigorously shaken and the precipitate then allowed to settle.

The final sediment should be uniform. If small gaps appear or the precipitate does not uniformly fill the lumen of the tube, then the apparatus should be again shaken, and the preeipitate be allowed again to settle.

The reading should always be taken the same number of hours after precipitation.

The urine should be taken from a mixed sample of the total daily urine.

If albumen is present it is better, although not absolutely necessary, for it to be removed by boiling in the usual manner.

The apparatus must always be kept away from the light during the estimation. It is well for the instrument to be during the estimation. It is well for the instrument to be
cleaned immediately after use, in order to avoid the formation of a sediment upon the sides of the glass tube.

When not in use the stopper and the plug of the stopcock should be kept apart from the tube, or kept loosely in position by the interposition of a piece of thin paper.

$$
\text { REFERENCES. }
$$

1 Purin Bodies of Foodstuffs, Sherratt and IIughes, 1902, and Sccond

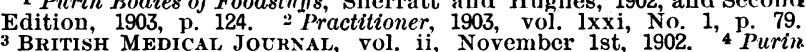
Bodies of Foodstuffs, p. 147 .

The manuscript of this paper was received by the Editor on October 14th, 1905.]

\section{ON CHEMIOTAXIS.}

BY J. O. WAKELIN BARRATT, M.D., B.Sc.LoNn., BRITISH MEDICAL ASSOCIATION RESEARCH STUDENT.

[From the Physiologisches Institut, Univer'sity of Göttingen.]

Historical.

THE study of chemiotaxis-the taxis or arrangement of motile organisms induced by chemical substances-was first commenced about twenty years ago. Historically, it may be said to take its origin to a considerable extent out of investigations on the allied phenomenon of galvanotaxis exhibited by free-swimming organisms. It is, therefore, desirable to refer briefly to the researches which have 
been carried out upon galvanotaxis before passing to those which have been directed to chemiotaxis.

Galvanotaxis was first observed by Hermann ${ }^{3}(1885)$ in connexion with embryonic frogs, but he did not carry his observations very far, and the first exhaustive study of this remarkable phenomenon was made by Verworn ${ }^{2}$ (1889), who, selecting the simplest organisms as likely to offer the most favourable opportunity of investigating both the manifestations and the conditions of production of galvanotaxis, carried out a series of beautifully-contrived experiments on free-swimming infusoria, and laid the foundations of our present knowledge of this process. Verworn studied galvanotaxis by placing water containing the infusoria in question in a cell, constructed oy placing small bars of clay upon a microscope slide (Fig. 1). Outside this cell non-polarisable electrodes were placed, between which an electric current was allowed to pass. When paramoecia are examined in

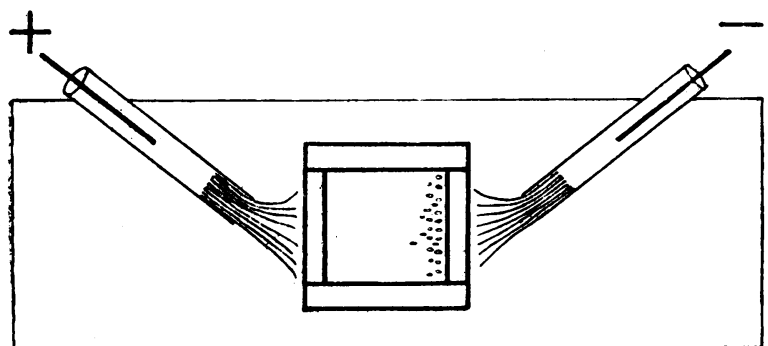

Eig. 1.-A small cell is constructed upon a microscope slide by means of bars of porous clay. Outside the cell are placed two non-polarisable electrodes. If paramoecia are put inside
the cell they swim towards the cathode during passage of the current.

this way it is found that on closure of the current they at once arrange themselves with the oral extremity pointing to the cathode, and the aboral end directed to the anode, and they then swim in the direction of the cathode. On reversing the current a change of movement in the oppasite direction occurs. Verworn found that galvanotaxis was exhibited by many rhizopoda, flagellata, ciliata, and bacteria, some of which turned to the cathode, others to the anode. The nature of this peculiar response of living organisms to the constant current formed the sub ject of further investigations by Ludloff ${ }^{3}$ (1895-6) Jennings (1897), Loeb and Budgett ${ }^{5}$ (1897), Pearl ${ }^{6}$ (1900), Carlgren (1900), Dale ${ }^{8}$ (1901), and Wallengren" (1902-3). The mechanism of the orientation followed by swimming to the cathode (in the case of paramoecium) was studied by Jennings. Loeb and Budgett sought to show that the movement to the cathode was conditioned by the production, during passage of the current, of alkali at the posterior (aboral) and acid at the anterior (oral) end of the organism; and it had been shown by Jennings that paramoecia under appropriate conditions of experiment move towards an acid liquid and away from an alkaline liquid. Considerable attention was now directed to the chemiotaxis of free-swimming infusoria. Attention also began to be directed to the behaviour of solid particles suspended in a liquid. Such particles may possess an electric charge, in which case they move to one of the electrodes of a constant battery immersed in the liquid. Such movement can be reversed by the addition of electrolytes to the liquid. Dale found that a similar reversal of the galvanotaxis of opalina and nyctotherus, infusoria existing in the frog's intestine, was obtained by changing the reaction of the liquid in which these organisms were placed, and that colpidium and paramoecium exhibited a reversed galvanotaxis on the addition of sodium chloride; but living organisms were considered not to be at all comparable to inert particles, owing to the obviously active, and not merely passive, character of their response to the constant current. It was shown by Coehn ${ }^{10}$ (1897) that such colloids as starch and dextrin moved towards the cathode, and Hardy ${ }^{11}$ (1899) found that the movement of colloidal proteid could be reversed by the addition of small amounts of acid or of alkali. Höber ${ }^{12}$ (1904) showed that under suitable conditions of experiment red blood cells were charged electrically, and Coehn and Barratt $^{13}$ (1905) showed that paramoecia possess a positive charge at the oral end, causing orientation of the organism, and leading to its movement, partly passive, partly active, to the cathode; they also found that galvanotaxis occurred when the fall of potential in the liquid containing the paramoecia was too small ( 0.2 volt) to cause electrolysis, and thus that the possibility of acid and alkali being produced at the opposite ends of the organism is excluded.

Chemiotaxis, which, as will readily be understood from the foregoing, is so closely associated with galvanotaxis, has been most often studied in connexion with infusoria. Two methods of observation have been most frequently employed: Fluid containing the infusoria is placed in a glass cell (Fig. 2), into which one end of a narrow tube containing the fluid to be tested dips; or a drop of the fluid to be tested is introduced into the cell by means of a fine pipette. The attraction or repulsion of the organisms in respect of the liquid tested is observed under a low

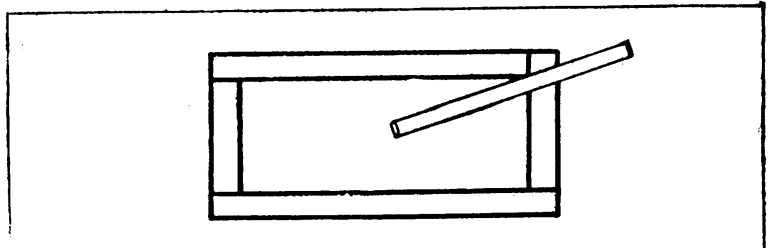

Fig. 2.-A cell containing paramoecia is made upon a microscope slide. In order to observe chemiotaxis, a glass tube of narrow its lower end dipping into the cells.

power of the microscope. In this way chemiotaxis of acids, alkalies, and salts has been studied. It was found by Loeb and Budgett ${ }^{14}$ that alkalies caused, in addition to their chemiotactic action, swelling of the cell protoplasm of paramoecia, recalling the swelling at the cathodic extremity caused by the constant current, and it may also be mentioned incidentally that concentrated saline solutions cause shrinking of the cell protoplasm. Dale ${ }^{15}$ (1900) showed that in the organisms he employed a parallelism between chemiotactic and galvanotactic response existed. Garrey ${ }^{16}$ (1900), working in J. Loeb's laboratory, studied, in the course of a very interesting research, more minutely the influence of individual ions in bringing about chemiotactic phenomena. But processes indicative or suggestive of chemiotaxis are by. no means confined to infusoria. Buchner ${ }^{17}$ (1890) investigated the conditions under which inflammatory exudations were caused by bacterial toxins, and came to the conclusion that the latter attracted leucocytes, and the conditions under which chemiotaxis of leucocytes in inflammatory states occurs were further studied subsequently by Massart and Bordet ${ }^{13}$ (1890). The phagocytosis of red blood cells first described by Metchnikoff and subsequently investigated by Sawtchenko (1902) and Barratt $^{20}$ (1905) has been attributed to chemiotaxis of leucoeytes by sensibilized red blood cells, and a. similar explanation of the phagocytosis of bacteria is equally tenable.

Again, in fertilization of the ovum, the movement of the spermatozoon to the ovum is conjectured to be another example of chemiotaxis ${ }^{21}$. Thus it is seen that chemiotaxis has been invoked to furnish the key to some of the supremely important processes of cell defence against bacteria and bacterial products, and of fertilization, but it must be conceded that before the occurrence of chemiotaxis as a determining factor in these processes can be regarded as established, more information is needed as to the exact mode in which these phenomena occur. Obviously the correctness of such deduetions depends upon the completeness with which the conditions under. which the simplest phenomena attributable to chemiotaxis take place are determined, for otherwise speculation is apt to take the place of ascertained fact. And here it may be observed that no consensus of opinion exists even in reference to the nature of the reaction of ciliated protozoa to acid and alkaline liquids, which are perhaps the simplest phenomena of this character and have received the largest amount of study, and yet are still a subject of discussion. Thus in oppasition to the more usually received opinion, namely, that a true chemiotaxis takes place, Jennings ${ }^{22}$ looks upon the response of paramoecia as a special motor response, which is independent of the kind of stimulus used, and holds that no true chemiotaxis takes place. It is clear that need exists for further investigation of the exact conditions under which the response of paramoecia to 
acids and alkalies occurs, and that such an investigation forms a necessary adjunct to research upon the more complex processes referred to above in which chemiotaxis appears to play an important rôle. It was therefore determined, as a preliminary to later observation on wandering cells, to study the nature of the action of acids and alkalies upon the living protoplasm of paramoecia, and in particular to endeavour to ascertain if the process in question is a chemical process, or is merely physical or physico-chemical in character. ${ }^{23}$ The present paper will also deal with a reinvestigation, in the light of the knowledge thus gained, of the chemiotaxis of paramoecium in respect of acids and alkalies.

\section{The Interaction of Protopl.asm with ACID and} Alikali.

In experiments with paramoecia, four data are required in order to define the conditions under which the experiments are made. In the first place, the concentration of the acid and alkaline solutions whose chemiotaxis is being tested must be accurately ascertained; in the second place, the character of the liquid in which the paramoecia are contained must be known; in the third place, the weight of the paramnecia used must be determined; and, lastly, the condition of the organisms employed must be as nearly as possible the same in the various series of experiments.

The concentration of the acid and alkaline solutions used for experiments on chemiotaxis has in the past been usually given in percentage form. This does not, however, withont further calculation, permit of a comparison of the relative number of molecules contained in the different solutions employed. It is therefore better to give instead the molecular strength, for, as will be seen later, solutions which produce an equal effect upon paramoecia differ widely in respect of percentage composition, this depending apon the molecular weight of the acids and alkalies employed, but, with few exceptions, are of equal or of very nearly equal molecular strength. In Tables I to VIII the concentration is equivalent.*

It is equally important to know the composition of the fluid in which the paramoecia employed for experiment are preserved. If the paramoecia during experiment remain in hay infusion or in some other culture medium it is necessary to know the molecular and ionic concentration of this liquid, its reaction and its capacity for taking up acid and alkali. Data of this kind are given in the next section. In the experiments detailed in this section the paramoecia were always kept in distilled water during experiment, so that these data are not required.

The weight of the paramoecia employed was determined by filling the tube of a haemocrit up to a convenient level with paramoecia, and then shaking the organisms out of the tube into water and counting them. $\dagger$ In this way the average volume of the individual paramoecia employed was ascertained, and by counting the total number of organisms used in a given experiment the total volume of paramoecia was calculated. From this the total weight was determined by multiplying the volume by the specific gravity of paramoecia, for which Jensen's estimate ${ }^{24}$ of 1.25 is taken. It is necessary to make a haemocrit determination with each batch of paramoecia, since the size of paramoecia is liable to great variation. If, however, it is merely necessary to ascertain that the weight of the paramoecia employed is inconsiderable compared with that of the acid or alkali used, and therefore insufficient to affect the concentration of the latter to an appreciable extent, it is sufficient to count the paramoecia employed.

The paramoecia used for experiment were separated from the medium in which they were cultivated by means of centrifugalization, and were preserved in distilled water for at least twenty-four hours before use. Shortly before commencing an experiment they were again washed with distilled water.

A further practical point of considerable importance in these experiments is to use apparatus made of glass which is as little soluble in water as possible. The need

* Carbonic and boric acids in the concentration sulitable for this investigation are dissociated like binary compounds, and their concentration is therefore reckoned in gramme-molecules per litre.

t By means a suitable modification of the Thoma-Zeiss method applied to the cnumeration of red blood-cells. for this precaution will be obvious when it is mentioned that the solutions of acid and alkali employed (cf. Tables I to IV) are of necessity very dilute. For this reason all the beakers, test tubes, and capillary tubes used were constructed of Jena combustion glass.

In testing the action of acids and alkalies. upon living paramoecia concentrations which rapidly killed the organisms were, as far as possible, avoided, for with such liquids obviously the action of acid and alkali might continue to be exerted upon the protoplasm after death. The solutions employed were therefore not greater than the minimal lethal concentration, by which is meant that concentration which killed the paramoecia in from ten to thirty minutes. The concentration of the strong mineral acids-hydrochloric, nitric, and sulphuric-which is fatal to paramoecia within this period of time, varies with different batches of paramoecia from $0.0001 \mathrm{n}$. (in the case of hydrochloric acid a 0.0004 per cent. solution) to $0.0003 \mathrm{n}$., and for the liydrates of potassium and sodium from $0.001 \mathrm{n}$. (in the case of potassium hydrate a $0.006 \mathrm{per}$ cent. solution) to $0.003 \mathrm{n}$. The lethal concentration of the weaker acids-formic, lactic, oxalic, tartaric, phosphoric, citric, and acetic-and of the hydrates of lithium, calcium, strontium, and barium lie somewhat below the above limits. On referring to the tables it will be seen that the concentrations employed usually allowed of the majority of the paramoecia used remaining alive at the end of the experiment, though usually so far injured that most were dead an hour later. Here attention may be called to an interesting sidelight which the study of the lethal concentration of acids and alkalies ${ }^{25}$ throws upon the action of these substances on living protoplasm. It was found that the weaker acids are as toxic as, or more toxic than, the strong mineral acids, yet the ionic concentration of the former in equally lethal strength is less than that of the latter, from which it may be surmised that the action of acids upon living protoplasm is a chemical one in which both positive and negative ions disappear, and that the effect on living protoplasm is in part dependent upon the negative ion. Clearly; if the action of acids were catalytic and dependent upon the $\mathrm{H}+$ ions, the concentration of the latter would be the same for all equally lethal concentrations, but this is not so. The extremely weak electrolytes carbonic acid, carbolic acid, boric acid, and hydrocyanic acid, are considerably less toxic than the acids already referred to ; their action upon the protoplasm of paramoecia would appear to be of a different order from that of the strong mineral acids, and their ionic concentration in equally lethal solutions is relatively as well as actually low. Similarly, it would appear that the lethal character of the bases is dependent on a chemical action, that both the $\mathrm{OH}-$ ions and the cations are involved, and that $\mathrm{Ba}++$ and $\mathrm{Sr}++$ ions conveyed a more lethal character to the effect on living protoplasm than an equivalent number of $\mathrm{K}+$ and $\mathrm{Na}+$ ions.

The crucial experiments which were made to determine the nature of the action of acids and alkalies upon living protoplasm, were carried out with the aid of the apparatus shown diagrammatically in Fig. 3. If paramoecia, previously carefully washed in distilled water, and then suspended in acid or alkali of lethal, or slightly sublethal,

TABLE I.--Examples of Corrected Gallanometer Readings taken fiom Table 2 .

\begin{tabular}{|c|c|c|c|c|c|}
\hline \multirow{2}{*}{ 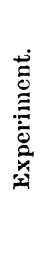 } & \multirow[b]{2}{*}{ Acid Employed. } & \multirow[b]{2}{*}{$\begin{array}{l}\text { In Concen- } \\
\text { tration of }\end{array}$} & \multicolumn{3}{|c|}{$\begin{array}{l}\text { Difference of Galvanometer } \\
\text { Readings at Beginuing } \\
\text { and End of Experiment. }\end{array}$} \\
\hline & & & 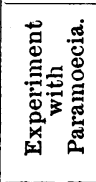 & 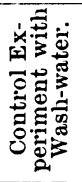 & 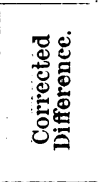 \\
\hline $\begin{array}{l}3 \\
7 \\
11 \\
13 \\
17 \\
18 \\
20 \\
23 \\
24 \\
28\end{array}$ & $\begin{array}{l}\text { Hydrochlloric acid } \\
\text { Nitric acid } \\
\text { Sulphuric acid } \\
\text { Formic acid } \\
\text { Lactic acid } \\
\text { Oxalic acid } \\
\text { Tartarie acid } \\
\text { Plosphoric acid } \\
\text { Citric acid } \\
\text { Acetic acid }\end{array}$ & $\begin{array}{ll}0.0001 & \mathrm{n} . \\
0.0003 & \mathrm{n} . \\
0.0001 & \mathrm{n} . \\
0.0001 & \mathrm{n} . \\
0.0001 & \mathrm{n} . \\
0.0001 & \mathrm{n} . \\
0.0001 & \mathrm{n} . \\
0.0002 & \mathrm{n} . \\
0.0001 & \mathrm{n} . \\
0.00015 & \mathrm{n} .\end{array}$ & $\begin{array}{l}-0.8 \\
-1.2 \\
0.00 \\
-0.32 \\
-0.40 \\
-0.25 \\
-0.50 \\
-0.70 \\
0.00 \\
-0.30\end{array}$ & $\begin{array}{r}-0.30 \\
=0.30 \\
=0.05 \\
+0.10 \\
=0.25 \\
=0.15 \\
-0.13 \\
0.00 \\
0.00 \\
0.00\end{array}$ & $\begin{array}{r}-0.50 \\
-0.90 \\
0.00 \\
-0.42 \\
-0.15 \\
-0.10 \\
-0.37 \\
-0.70 \\
0.00 \\
-0.30\end{array}$ \\
\hline
\end{tabular}


TABLE II.-Diminution of Concentration of Acid Solutions Brought About by Living Paramoecia.

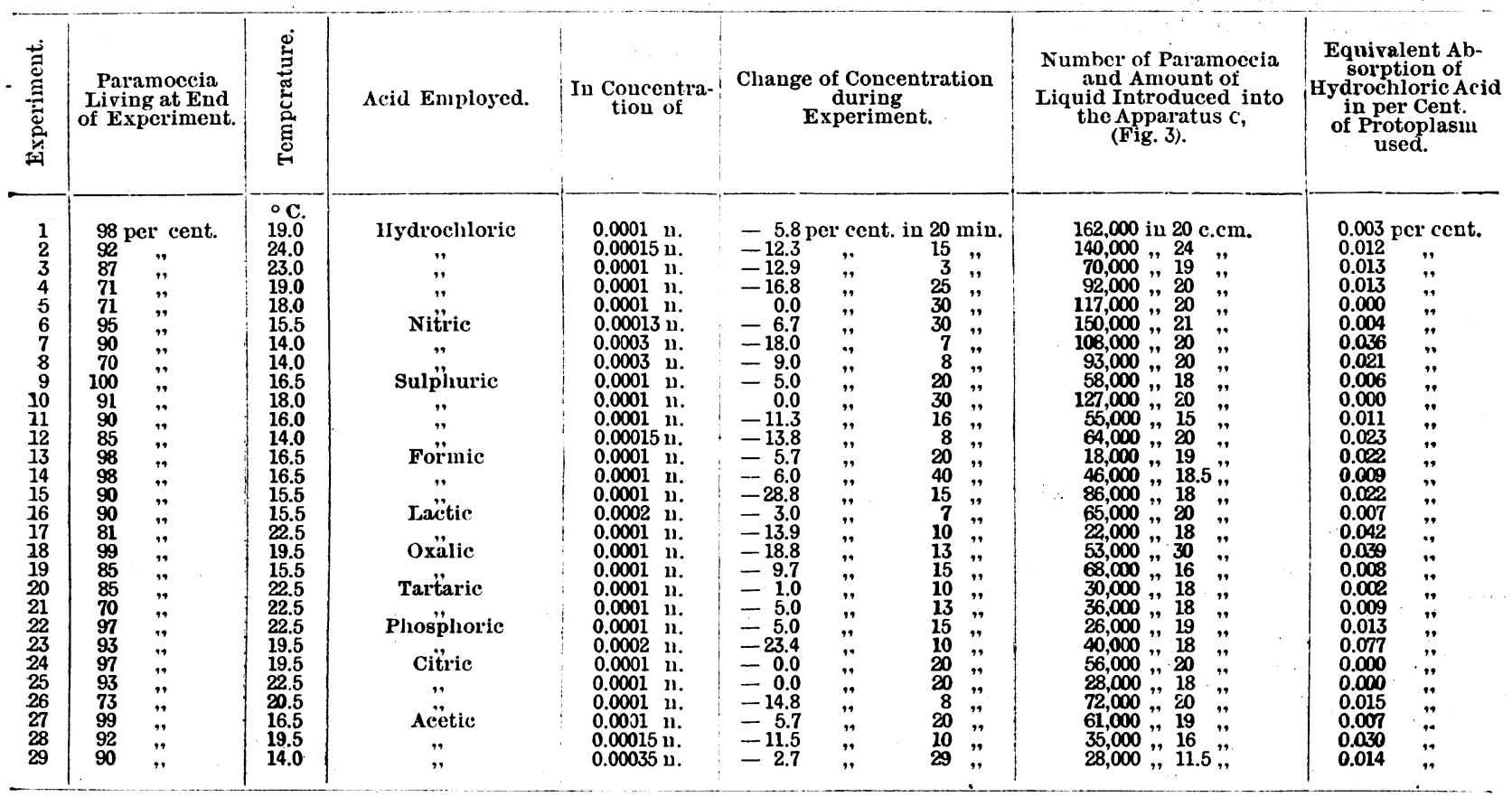

TABLE III.-Diminution of Concentration of Alkaline Solutions Brought About by Living Paramoecia.

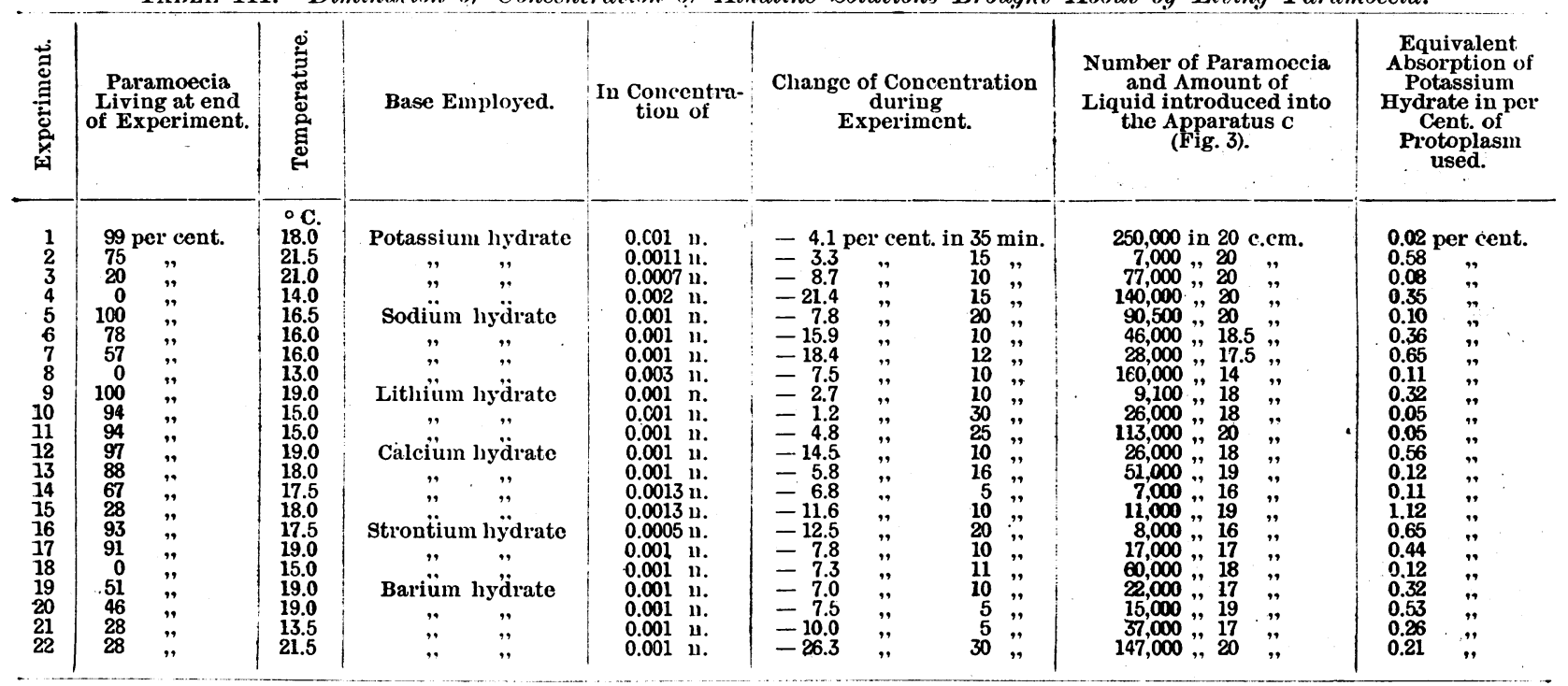

TABLE IV.-Diminution of Concentration of Acid and Alkaline Solutions. Brought About by Living Paramoecia: Determinations Made with the Aid of a Palladium-hydrogen Concentration Cell.

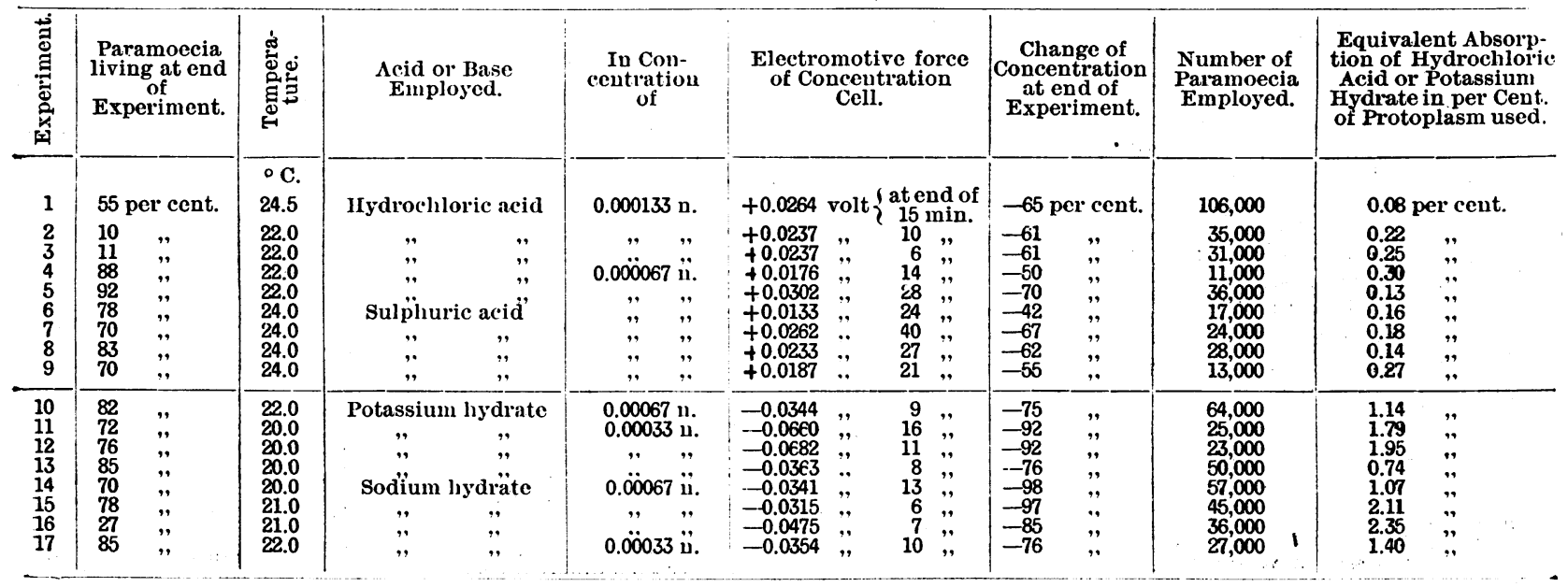


strength, are placed in the apparatus $c$, and the relative conductivity of the liquid tested by momentarily closing the circuit formed by the accumulator $\Lambda$ and galvanometer $\mathrm{a}$, and noting the galvanometer reading, ${ }^{*}$ it is found that the conductivity of the

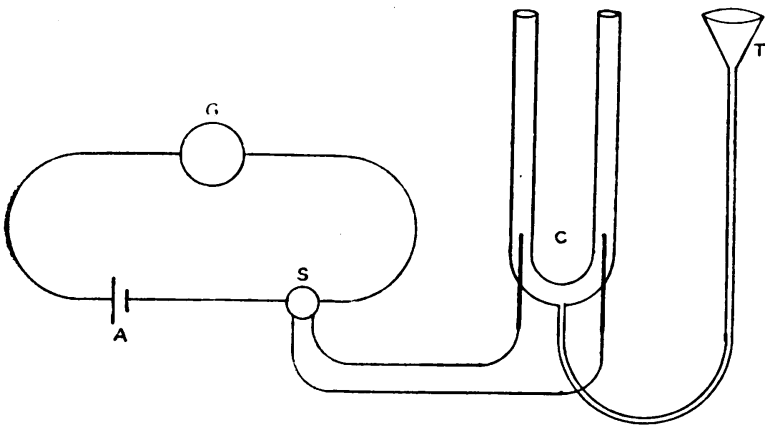

Fig. 3. -A, aceumulator; (a, galvanometer : s, rerersible ker for closing current in e ther direction; c, U-tube containing platinum electrc des ; T, glass funnel.

liquid in $\mathbf{c}$ shows a steady diminution as the experiment proceeds, while the paramoecia soon become sluggish in their movements, or cease to move. If the acid or alkaline solution placed in $\mathrm{c}$ is made up with distilled water containing no paramoecia, then a much slower fall of conductivity takes place, or the conductivity may remain constant during the period of experiment. If the acid or alkaline solution is made up with the distilled water which has been used for washing the paramoecia before the experiment, a more marked fall takes place, which is, however, less than that occurring when paramoecia are placed in c. It is therefore necessary to correct the actual experiment, in which paramoecia suspended in acid or alkaline liquid are placed in $c$, by means of control experiments, in which wash-water and acid or alkaline solution are placed in $c$, the fall of conductivity noted in the contral experiment during the period of observation being subtracted from that taking place in the actual experiment in the same period of time. The extent of these corrections is given in Table I, in which the corrections required for some of the experiments, selected at random, given in Table II, are exhibited. The corrections amount to an average of about 28 per cent. of the uncorrected result. They are obviously too high, since the wash-water contains more dissolved matter capable of taking up acid and alkali than the fresh distilled water in which the paramoecia are placed after washing would contain. The latter would, however, also probably receive some dissolved material derived from paramoecia accidentally injured during the process of washing, and it has therefore been thought better to make use of over-corrected results than to neglect applying any corrections whatever.

The extreme dilution of the acid and alkaline solutions employed for experiment (Tables II and III) renders titration of these solutions by ordinary volumetric methods unsuitable. It was found, however, easy to judge of any accidental error in making up the solutions by noting the extent of the initial galvanometer deflection ( 4 , Fig. 3) when the same difference of potential of the accumulator A was maintained in a series of experiments, the extent of the deflections given by the varying concentrations of acid and alkaline liquid introduced into $c$ in control experiments having previously been carefully determined. In this way it was easy to ascertain, at the time of commencing an experiment, if the solutions employed possessed the desired concentration.

In Table II a series of twenty-nine experiments, corrected in the manner above described, is given, in which paramoecia are exposed in the apparatus $c$ (Fig. 3) to the action of acids. These experiments show (omitting for the present Experiments 5, 10, 24, and 25, which will be again referred to later) a diminution of the acid, measured by the fall of conductivity during the period of experiment, lasting from three to forty minutes, of from 1 per cent. to 28.8 per cent. (Table II, col. 6). From this disappearance of acid in the presence of paramoecia, it

* This is more convenient than determining the actual conductivity by means of Kohlrausch's method, and permits at the same time of the condition of the paramoecia being readily observed hy the
readiness or sluggishness with which galranotaxis takes place. follows that the action rif acid upon protoplasm is a chemical action in which acid is used up. Moreover, since, as will be seen on reference to col. 2, the paramoecia remain for the most part (70 per cent. to 100 per cent.) living at the close of the experiment, it is seen that this action is exerted upon living protoplasm. The duration of the experiment was determined by the appearance of the paramoccia; as soon as their movements seemed to be diminishing in vigour the experiment was brought to an end, the paramoecia were removed from the apparatus $c$ (Fig. 3) and without any delay counted, special note being taken of the percentage of dead paramoecia. The experiments were made at room temperature $-14^{\circ} \mathrm{C}$. to $24^{\circ} \mathrm{C}$. - some being made in the spring, some in the hot summer months. The number of paramoecia put into the apparatus c (Fig. 3) varied (col. 7, Table II) from 18,000 to 162,000 , and the amount of liquid in which they were contained from $11.5 \mathrm{c.cm}$. to $30 \mathrm{c.cm}$. In consequence of these variations in the individual experiments a close comparison of the results given in col. 6 is not attainable without reduction to a common standard. In order, therefore, to afford an idea of the relative amounts of protoplasm and acid reacting, there is given in the last. column of Table II the amount of acid absorbed by one hundred parts of protoplasm in the different experiments.

To render the comparison more easy, and to avoid the inconvenience caused by the difference in molecular weight exhibited by different acids, these results are calculated for equivalent amounts of liydrochloric acid. By multiplying the figures given in col. 8 by 0.274 , the number of gram-molecules of acid per kilogram of protoplasm is obtained, but the percentage form given in the table is practically the more convenient. From these results it will be seen that the living protoplasm of paramoecium absorbed 0.003 per cent. to 0.077 per cent. of its weight of hydrochloric acid or of equivalent amounts of other acids during the period of experiment. The proportion of acid reacting is thus very small,* but it must be recollected that in these experiments the living protoplasm has not taken up the maximum amount of acid ; to determine the latter is impracticable, owing to the impossibility of separating the action of acid on living from that on dead protoplasm, if the action is continued after more than a small number of the paramoecia have become motionless.

A similar series of experiments made with alkaline liquids is given in Table III. Owing to the diminished toxicity of alkalies as compared with acids, stronger concentrations could be employed-namely, from $0.0005 \mathrm{n}$. to $0.003 \mathrm{n}$. In other respects the experiments do not differ materially from the former series. In these experiments, as in those with acids, a diminution of concentration of alkali in the presence of living protoplasm took place, amounting to from 1.2 per cent. to 26.3 per cent. of the alkali originally present in the apparatus $\mathrm{C}$ (Fig. 3). It is clear, therefore, that alkalies, like acids, attack living protoplasm by entering into a chemical reaction with it, in the course of which the alkali is used up. In the last column of Table III a calculation is made of the equivalent amount of potassium hydrate entering into reaction with 100 parts of living protoplasm. This ranges from 0.02 per cent. to 1.12 per cent., but these amounts of course do not represent the maximum amounts which can react upon living paramoecia. Since paramoecia give off carbon dioxide, ${ }^{20}$ it became necessary to calculate the maximum amount of this substance which might be given off during the period of experiment, and this was found not to exceed in any experiment an amount capable of neutralizing 10 per cent. of the alkali introduced into $\mathrm{c}$ (Fig. 3). The amount actually produced was probably much smaller than the calculated maximum, so that the accuracy of the results given in Table III is not impaired to any serious extent by any carbon dioxide produced during the period of experiment.

Comparing Tables II and III, it will be noted that the amount of acid taken up by the living protoplasm of paramoecia is much less than that of alkali, as would be expected from the greater toxicity of the former. The ratio of equally lethal concentrations of mineral acid and caustic alkali is approximately $1: 14$, while the average ratio of the concentration of the acid and alkali reacting in Tables II and III with living protoplasm is $1: 16$, or if

* If calculated for dry protoplasm, the percentages would, of course be correspondingly higlier. 
gram-molecules per kilogram of protoplasm are taker, $1: 10.5$.

It is to be observed that the rate of diminution of conductivity after the addition of paramoecia to acid and alkaline liquids was very rapid at first, so that some difficulty was experienced in making the first galvanometer reading. The rate of disappearance of acid and alkali then rapidly diminished, the chief fall of conductivity occurring during the first ten to fifteen minutes, and the rate of fall afterwards becoming slow, while the paramoecia at the same time usually became sluggish in their movements, so that it was not generally practicable to continue the experiments for periods exceeding twenty minutes.

Owing to the extremely dilute solutions necessarily made use of in these experiments, and the small amounts of fluid employed, the usual procedures of quantitative analysis were not available. After many attempts had been made to determine the nature of the action of acids and alkalies upon living protoplasm by means of experiments which were purely qualitative in character, ${ }^{27}$ the method above described was ultimately chrosen as affording quantitative data. Subsequently the above work was repeated, another method being employed, which will now be described, and which is more delicate while avoiding some of the inconveniences of the method depieted in Fig. 3.

The essential feature of these new estimations is the use of palladium-hydrogen electrodes in order to ascertain the fall of concentration of acid and alkali which takes place in the presence of paramoecia. The apparatus employed is shown diagrammatically in Fig. 4. D is an accumulator having a potential of about two volts; $\mathrm{c}$, a coil rheostat, and $w$, a resistance box, were so arranged that between the two ends of $c$ a potential difference of 0.1 volt existed. By means of the sensitive galvanometer $G$ the potential difference of the two palladium-hydrogen electrodes in the concentration cell $\mathrm{K}$ could be neutralized after Poggendorff's method by means of a sliding contact with c. In charging and using the palladium-hydrogen electrodes the directions given by Fraenkel ${ }^{28}$ were followed. In making an experiment acid (or alkaline) solutions of equal concentration were placed in the apparatus $K$, consisting of two vertical tubes connected by a horizontal cross-piece provided with a stop-cock, not shown in the figure. Into one of the tubes paramoecia, carefully washed in distilled water as in the previous experiments, were also placed. Since both tubes contained at the commencement of an experiment the same concentration of acid or alkali, no difference of potential between the palladium-hydrogen electrodes at first exists. Immediately after mixture a rapidly-increasing potential differenee between the electrodes appears, which after a time increases more and more slowly. The experiments were in every case brought to a close as soon as a distinct defect of movement of the paramoecia could be recognized. To enable the determination of the difference of potential to be more readily made a neutral salt (sodium chloride or sulphate) was added in $0.02 \mathrm{n}$. concentration in all experiments recorded in Table IV, except 14 and 15. The difference of concentration between the two tubes of the apparatus $\mathrm{K}$ (Fig. 4,) was calculated from the formula,

$$
\pi=\frac{\mathrm{R} \mathrm{T}}{\mathrm{F}} \ln \frac{\mathrm{C}}{\overline{\mathrm{C}}_{1}}
$$

where $R$ is the gas constant (8.31), $T$ is the absolute temperature, and $F$ the electric charge of a gram-ion (96580). If the temperature of experiment is $22^{\circ} \mathrm{C}$., then

$$
\pi=\frac{8.31 \times(273+22) \times 2.3026}{96580} \log . \underset{\mathrm{C}_{1}}{\mathrm{C}}
$$

$=0.058 \log \cdot \frac{\mathrm{C}}{\mathrm{C}_{1}} \mathrm{C}$ being the initial concentration,

$\mathbf{C}_{1}$ being the concentration of the acid in the tube containing paramoecia, at the close of the experiment.* If no

\footnotetext{
* In Experiment 3, for example, $\pi=0.0237$ volt. Therefore $0.058=0.408=\log . \frac{\mathrm{C}}{\mathrm{C}_{1}}$ that is, $\frac{\mathrm{C}}{\mathrm{C}_{1}}=10^{.408}=2.56$, but $\mathrm{C}=0.000133$. Therefore $\mathrm{C}_{1}=\frac{0.000133}{2.56}=0.000052$. Simee $\frac{0.000133}{0.000052}=\frac{100}{39}$, the reduction of coneentration is 61 per cent:
}

neutral salt is added to the solutions placed in $\mathrm{K}$ the formula

$$
\pi=\frac{2 n \cdot R \mathrm{~T}}{\mathrm{~F}} \ln \frac{\mathrm{C}}{\mathrm{C}_{1}}
$$

must be used, in which " $n$ " is the transport number of the cation of the acid.

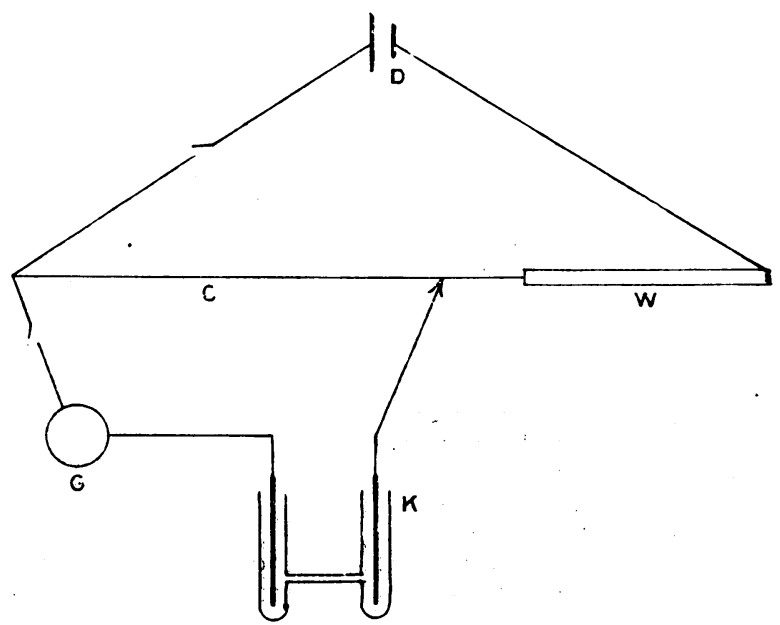

Fig. 4.-c, wire resistance with sliding contact; w, 'resistance-box $\mathbf{D}$, accumulator ; $\mathbf{k}$, concentration cell ;. ( ;, galvanometer.

In Table IV a series of determinations made with paIladium-hydrogen electrodes, but in other respects conducted as in the previous experiments, is given. These experiments show, like the former ones, that acid and alkali react with living protoplasm, and are used up in the process. It is seen, also, that a much greater disappearance of acid (42 per cent. to 70 per cent., column 7 ) and alkali ( 75 per cent. to 98 per cent.) is observed than in the former series. The amount of acid and alkali which in these experiments reacted with living protoplasm, when expressed in percentage terms of the latter, is likewise much higher than in Tables II and III, amounting to 0.08 per cent. to 0.30 per cent. for acid and 0.74 per cent. to 2.35 per cent. for alkali, the averages being 0.19 per cent. and 1.57 per cent. as against 0.20 per cent. and 0.32 per cent. in the former tables.

Before passing to consider these differences further, attention may be called to the fact that hydrogenpalladium electrodes measure directly not the concentration of the whole acid or alkali employed, but only the $\mathrm{H}+$ and $\mathrm{OH}^{-}$- ionic concentration. An attempt to measure the change of concentration of the cations of the alkalies or the anions of the acids is not at present practicable, except in the case of hydrochloric acid, where the $\mathrm{Cl}-$ ions may be measured by means of calomel electrodes. Such measurements were carried out, and led to the remarkable result that the $\mathrm{Cl}-$ ions, instead of diminishing when paramoecia were immersed in hydrochloric acid of lethal or slightly sublethal concentration, actually increased in amount. The cause of this increase was found on farther investigation to be due to the discharge of electrolytes from the injured protoplasm of the paramoecia into the liquid surrounding them. That this is so can readily be shown by adding carefully-washed paramoecia in sufficient amount to dilute nitric acid and boiling. The boiled liquid is found to turn cloudy on the addition of silver nitrate, while when a control experiment with the distilled water used for washing the paramoecia is made no cloudiness or only a faint trace is visible.

The discharge of electrolytes by dead protoplasm* explains, in part at any rate, the low results obtained in Tables II and III, in which the fall of conductivity does not represent the whole of the diminution of concentration caused by paramoecia, owing to the lessening of the reduction of conductivity brought about by the discharge of electrolytes into the fluid. The same fact affords also an explanation of the circumstance already alluded tothat in some of the experiments recorded in Table II no diminution of conductivity was brought about by para-

* It is well known that the conduetivity of protoplasm increases after death. The resistance of tissues rich in icells is considerably
diminished after their protoplasm has been coagulated' by heat 
moecia. The extent of the error introduced by this behaviour of paramoecia cannot be estimated owing to the impossibility of determining the actual amounts of electrolytes discharged, these being too small to be estimated by ordinary chemical methods. It is to 'be observed that the paramoecia were present in considerable excess compared with the acid and alkali. As this point may be of interest to the reader, the relative amounts of paramoecia and acid or alkali present in the experiments in Table IV are given in Table V. The average ratio of paramoecia to acid is $335: 1$ and to alkali $66: 1$.

TABLE V.-Showing the Relation of Paramoecia to Acid and Alkali employed in the Experiments given in Table IV.

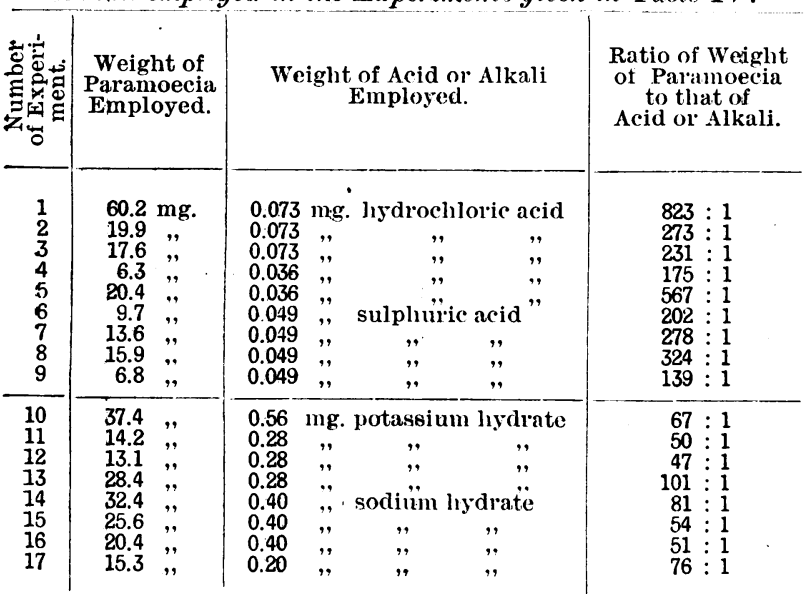

Chemiotaxis of Paramoficia.

Up to the present the action of acids and alkalies upon living protoplasm has alone been studied, and has been shown to be of the nature of a chemical reaction in which acid and alkali are used up, and not a merely catalytic process like the action of acids in inverting cane sugar or example, in which the concentration of acid remains unchanged. It now remains to investigate the action of acids and alkalies in influencing the movement or aggregation of parameecia, having regard to the data enumerated at the beginning of the preceding section as necessary to define the conditions of experiment, data which have usually left out of consideration or imperfectly given in most published researches. In addition, in all the experiments about to be described, control experiments have at the same time been performed (by employing tubes of the same size and shape as those containing acid or alkali, but filled with the same fluid as that in which the paramoecia are immersed). Finally an attempt has been made to give an approximately quantitative character to these observations made upon the chemiotaxis of paramoecia.

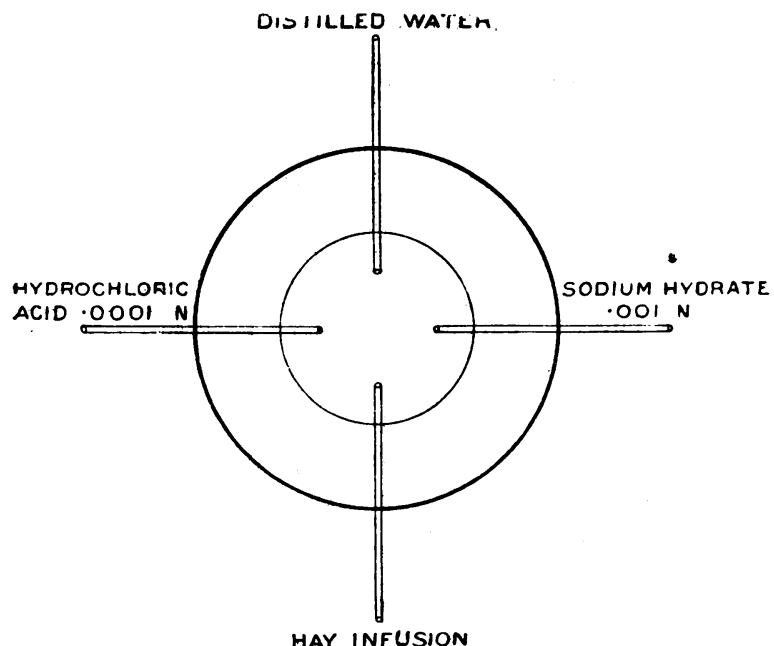

Fig. 5.-The outer circle represents the outline of a wateli-glass, which is filled, to the extent indicated by the inver circle with fluid contaiuing paramoecia. Four glass tubes are placed in the watch-glass, containing respectively (1) hydrochloric acid solution ; (2) distilled water; ; (3) solution of sodium
hydrate : and (4) liay infusion.
The experiments were made by placing paramoecia at room temperature in a watch-glass (Fig. 5) in which were laid obliquely, with the lower end only dipping in the watch-glass, tubes made of Jena combustion glass, containing the acid or alkaline fluid to be tested. The tubes had an internal diameter varying from $0.3 \mathrm{~mm}$. to $0.8 \mathrm{~mm}$. ; in each individual experiment, however, the tubes were cut from the same piece, and were of the same diameter. At the end of thirty minutes the tubes were removed and the paramoecia they contained counted. At the same time, in every experiment, an answer to the question, What would happen if the tubes were filled, not with acid or alkali, but with the fluid (distilled water or hay infusion) in which the paramoecia contained in the watehglass were immersed? was provided by the use of control tubes as already mentioned. By. comparing the results obtained in the actual and in the control experiments, the chemiotaxis of paramoecia is determined and may be expressed in an approximately quantitative form by stating the number of paramoecia present in the testing tube, at the close of the experiment, in percentage terms of those present in the control tube. The acid or base introduced into the testing tubes was of lethal or sublethal concentration. The fluid in the watch-glass, in which the paramoecia were immersed, was in some of the experiments distilled water (Table VI), but since in some

TABLF VI.-Experiments upon Chemiotaxis made with Paramoecia in Distilled Water, the Arrangement shoum in Fïg. 5 being Employed.

\begin{tabular}{|c|c|c|c|c|c|}
\hline \multirow{2}{*}{ 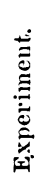 } & \multirow{2}{*}{$\begin{array}{l}\text { Acid or Base } \\
\text { Employed. }\end{array}$} & \multirow{2}{*}{$\begin{array}{l}\text { Concentra- } \\
\text { tion of Acid } \\
\text { or base. }\end{array}$} & \multicolumn{3}{|c|}{$\begin{array}{l}\text { Number of Paramoecia } \\
\text { Present at End of Thirty } \\
\text { Miuutes in Tube } \\
\text { containing }\end{array}$} \\
\hline & & & $\begin{array}{c}\text { Acid or } \\
\text { Base. }\end{array}$ & $\begin{array}{l}\text { Distilled } \\
\text { Water. }\end{array}$ & $\begin{array}{l}\text { Hay In- } \\
\text { fusion. }\end{array}$ \\
\hline $\begin{array}{r}1 \\
2 \\
3 \\
4 \\
5 \\
6 \\
7 \\
8 \\
9 \\
10 \\
11 \\
12 \\
13 \\
14 \\
15\end{array}$ & 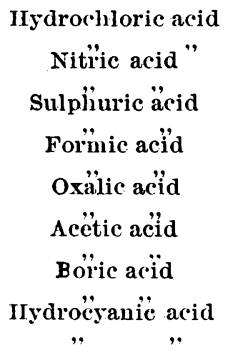 & 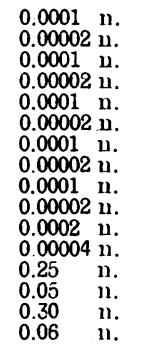 & $\begin{array}{r}2 \\
80 \\
41 \\
20 \\
130 \\
80 \\
180 \\
110 \\
90 \\
96 \\
2 \\
76 \\
0 \\
19 \\
0 \\
31\end{array}$ & $\begin{array}{r}80 \\
150 \\
200 \\
0 \\
110 \\
83 \\
120 \\
48 \\
160 \\
156 \\
113 \\
55 \\
60 \\
83 \\
71 \\
23\end{array}$ & $\begin{array}{l}1 \\
2 \\
0 \\
0 \\
2 \\
0 \\
0 \\
0 \\
0 \\
0 \\
0 \\
0 \\
1 \\
0 \\
1 \\
0\end{array}$ \\
\hline $\begin{array}{l}17 \\
18 \\
19 \\
20 \\
21 \\
22 \\
23 \\
24 \\
25 \\
26 \\
27 \\
28 \\
29 \\
30\end{array}$ & 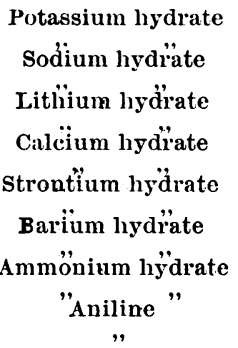 & 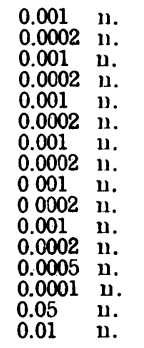 & $\begin{array}{r}0 \\
0 \\
0 \\
85 \\
5 \\
25 \\
0 \\
0 \\
0 \\
3 \\
0 \\
0 \\
1 \\
97 \\
1 \\
0\end{array}$ & $\begin{array}{r}198 \\
6 \\
80 \\
151 \\
120 \\
48 \\
110 \\
80 \\
113 \\
55 \\
160 \\
153 \\
60 \\
83 \\
71 \\
23\end{array}$ & $\begin{array}{l}0 \\
0 \\
2 \\
0 \\
0 \\
2 \\
0 \\
0 \\
0 \\
0 \\
0 \\
1 \\
0 \\
1 \\
0\end{array}$ \\
\hline
\end{tabular}

of the published experiments on the chemiotaxis of paramoecia the culture liquid has sometimes been employed, the experiments were repeated with paramoecia contained in the hay infusion in which they had been cultivated (Table VII). In addition, experiments were made in which the chemiotaxis of paramoecia in distilled water towards tubes filled with hay infusion was noted, as also that of paramoecia in hay infusion towards tubes filled with distilled water (Tables VI and VII).

The four conditions of experiment mentioned in the previous section require but little further consideration here. With respect to the first condition, it may be mentioned that very little loss of concentration by diffusion of the liquid contained in the tubes is to be feared, for if the tubes were filled with coloured liquid they preserved their. colour unchanged during the period of experiment. With regard to the fourth condition, it is to be observed that the experiments recorded in Tables VI and VII were made with paramoecia taken from the same stock jar as those 
employed in Table VII, and that both series of experiments were carried out at the same time.

Before passing to these experiments, the physicochemical characters of the hay infusion must be described. They were investigated in the following way: In the first place the molecular concentration of the liquid was determined be ascertaining by means of a Beckmann's apparatus, the lowering of its freezing point. This was found to correspond to a $0.031 \mathrm{n}$. solution (completely undissociated). Next, the conductivity of the hay infusion was determined. Since the ions present were unknown, the ionic concentration could not be calculated from the conductivity, but an idea of the degree of the ionic concentration may be obtained by calculating the ionic concentration of sodium chloride, which possesses the same conductivity, and this, which amounted to 0.0114 n., will be adopted as approximately representing the actual ionic concentration. Next, the amount of acid which the hay infusion was capable of neutralizing before its reaction became acid with methyl-orange as indicator was determined, and was found to correspond to a $0.011 \mathrm{n}$. solution of hydrochloric acid. Similarly, the amount of alkali which required to be added to the hay infusion before its reaction became alkaline to phenolphthalein was found to correspond to a $0.0024 \mathrm{n}$. solution of potassium hydrate. Finally, the $\mathrm{H}+$ and $\mathrm{OH}-$ concentration was determined by means of palladium-hydrogen electrodes, and was found to be almost exactly the same as that of pure water, the hay infusion being, therefore, a neutral fluid. The above results may conveniently be summarized as follows:

$$
\begin{aligned}
& \text { Total molecular coneentration ... ... } 0.031 \mathrm{n} \text {. } \\
& \text { Ionic concentration... … (approximately) } 0.0114 \mathrm{n} \text {. } \\
& \text { concentration of bases combined with } \\
& \text { weak acids } \ldots \text {... } \ldots \text { acids, } \ldots \\
& \text { combined with weak bases ... } \\
& \mathrm{H}+\text { ionic concentration }
\end{aligned}
$$

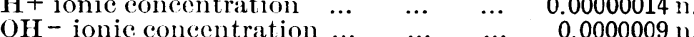

The method employed in these experiments, that of introducing into a liquid containing paramoecia tubes filled with the solutions to be tested (Fig. 5), was adopted in preference to that of introducing drops of solution or tubes filled with fluid much above the minimum lethal concentration, because, although in the latter modes of experimenting the grouping of paramoecia is often highly characteristic, yet the exact conditions of experiment, in respect of acid and base, as the experiment proceeds are uncertain.

When experiments after the method shown in Fig. 5 are made, the attention of the observer is at once struck by the circumstance that paramoecia frequently pass in large numbers into the tubes of acid and alkali. The density of the population of paramoecia which the tubes possess at the end of half an hour will be appreciated if the actual number of paramoecia given in Tables VI and VII is noted and it is borne in mind that the average content of the tubes is only about 12 cubic millimetres. If therefore no control experiments were made the conclusion would naturally be arrived at that a strong positive chemiotaxis was exerted by the acid and alkaline contents of the tubes upon paramoecia. When, however, the number of paramoecia passing into control tubes is noted, it is found to be still greater. This is very noticeable when the paramoecia in the watch-glass are contained in hay infusion and it is also marked when distilled water is used, though in this case in some of the experiments, to be referred to later, the relation is reversed (cf. Table VIII).

From the above observations it is clear that no conclusion can safely be drawn from experiments upon chemiotaxis, unless at the same time control experiments are made, and hesitation must be felt in accepting the conclusions which in the past have been drawn from observations unaccompanied by control experiments. It would be interesting to speculate upon the cause of the passage of paramoecia in such large numbers into the control tubes, but this would considerably increase the length of this paper and will, therefore, be deferred until further data have been obtained respecting the physical conditions present in such experiments.

The next point which calls for attention is the disincli-

\begin{tabular}{|c|c|c|c|c|c|}
\hline \multirow{2}{*}{ 节 } & \multirow{2}{*}{$\begin{array}{l}\text { Acid or Base } \\
\text { Employed. }\end{array}$} & \multirow{2}{*}{$\begin{array}{l}\text { Concentra- } \\
\text { tion of } A \text { cid } \\
\text { or Base. }\end{array}$} & \multicolumn{3}{|c|}{$\begin{array}{l}\text { Number of Paramoecia } \\
\text { Present at End of Thirty } \\
\text { Minutes in Tube } \\
\text { containing }\end{array}$} \\
\hline & & & $\begin{array}{c}\text { Acid or } \\
\text { Base. }\end{array}$ & \begin{tabular}{|} 
Distilled \\
water.
\end{tabular} & $\begin{array}{l}\text { Hay In- } \\
\text { fusion. }\end{array}$ \\
\hline $\begin{array}{r}1 \\
2 \\
3 \\
4 \\
5 \\
6 \\
7 \\
8 \\
9 \\
10\end{array}$ & 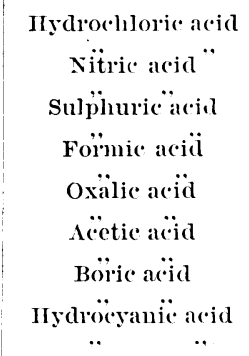 &  & $\begin{array}{c}5^{5 *} \\
216 \\
1 \\
2 \\
2 \\
40 \\
70 \\
83 \\
60 \\
167 \\
18 \\
63 \\
19 \\
40 \\
0 \\
24\end{array}$ & $\begin{array}{l}50^{*} \\
62 \\
4 \\
6 \\
1 \\
0 \\
3 \\
60 \\
56 \\
85 \\
0 \\
33 \\
25 \\
66 \\
27 \\
61\end{array}$ & $\begin{array}{l}37 * * \\
169 \\
25 \\
35 \\
28 \\
45 \\
273 \\
163 \\
208 \\
203 \\
110 \\
218 \\
120 \\
211 \\
25 \\
183\end{array}$ \\
\hline $\begin{array}{l}17 \\
18 \\
19 \\
20 \\
21 \\
22 \\
23 \\
24 \\
25 \\
26 \\
27 \\
28 \\
29 \\
30 \\
31 \\
32\end{array}$ & 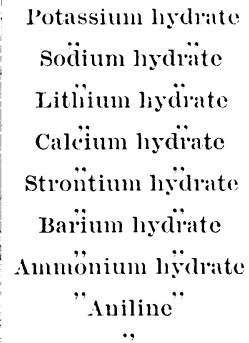 & 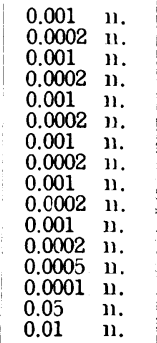 & $\begin{array}{l}0 \\
0 \\
1 * * \\
60 \\
45 \\
55 \\
0 \\
3 \\
35 \\
21 \\
3 \\
55 \\
10 \\
78 \\
1 \\
2\end{array}$ & $\begin{array}{c}4 \\
6 \\
51 * * \\
60 \\
3 \\
60 \\
1 \\
0 \\
0 \\
33 \\
56 \\
86 \\
25 \\
60 \\
27 \\
62\end{array}$ & $\begin{array}{l}25 \\
35 \\
36 * * \\
169 \\
267 \\
158 \\
28 \\
45 \\
110 \\
222 \\
208 \\
203 \\
120 \\
212 \\
25 \\
183\end{array}$ \\
\hline
\end{tabular}
nation of paramoecia in distilled water to enter tubes containing the hay infusion in which they were originally
TABLE VII.-E.tperiments upon Chemiotaxis made with Paramoecia in Hay Infusion, the Arranyement shown in Fig. 5 being Employed.

cultivated, and for paramoecia in hay infusion to pass into tubes containing distilled water. The negative taxis observed is very strong in the former case (Table VI), but is also marked in the latter (Table VII). It is obvious that here we have to do with phenomena dependent upon change of concentration, the chemical composition of the fluids used being apparently of less importance than their physico-chemical properties. Neither hay infusion nor distilled water can be regarded as properly speaking toxic, since paramoecia can live in either (in distilled water for seven to fourteen days). It is to be noted that paramoecia in distilled water are more sensitive to change of osmotic tension than is the rase when immersed in hay infusion (cf. Tables VI and VII.)

We now return to the influence of acids and alkalies upon the movement and aggregation of paramoecia. As already mentioned, their influence is generally to reduce the number of paramoecia entering the testing tubes.

\begin{tabular}{|c|c|c|c|c|c|}
\hline \multirow{2}{*}{ Acidor Base. } & & \multicolumn{2}{|c|}{$\begin{array}{l}\text { Paramoecia in Dis- } \\
\text { tilled Water placed } \\
\text { in Watcli-glass. }\end{array}$} & \multicolumn{2}{|c|}{$\begin{array}{c}\text { Paramoecia in Hay } \\
\text { Infusion placed iu } \\
\text { Watch-glass. }\end{array}$} \\
\hline & & $\begin{array}{c}\text { Stronger } \\
\text { concentra- } \\
\text { tion. }\end{array}$ & $\begin{array}{l}\text { Weaker } \\
\text { Concentra- } \\
\text { tion. }\end{array}$ & $\begin{array}{c}\text { Stronger } \\
\text { Concentra- } \\
\text { tion. }\end{array}$ & $\begin{array}{l}\text { Weaker } \\
\text { Concentra- } \\
\text { tiou. }\end{array}$ \\
\hline 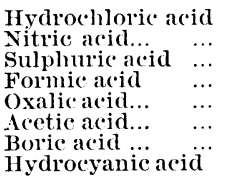 & \begin{tabular}{l|l|}
$\cdots$ & \\
$\cdots$ & \\
$\cdots$ & \\
$\cdots$ & \\
$\cdots$ & \\
$\cdots$ & \\
$\cdots$ &
\end{tabular} & $\begin{array}{r}2.5 \\
20.5 \\
118.0 \\
130.0 \\
54.2 \\
1.8 \\
0.0 \\
0.0\end{array}$ & $\begin{array}{r}53.3 \\
- \\
96.4 \\
230.0 \\
61.5 \\
138.0 \\
22.9 \\
135.0\end{array}$ & $\begin{array}{r}13.5 \\
4.0 \\
7.2 \\
25.6 \\
28.8 \\
16.4 \\
15.8 \\
0.0\end{array}$ & $\begin{array}{r}127.8 \\
58.7 \\
88.9 \\
51.0 \\
82.3 \\
28.9 \\
18.9 \\
13.1\end{array}$ \\
\hline $\begin{array}{l}\text { Potassium hydrate } \\
\text { Sodium hydrate... } \\
\text { Lithium liydrate... } \\
\text { Calcium hydrate... } \\
\text { Strontium hydrate } \\
\text { Barium hydrate... } \\
\text { Ammonium hydrate } \\
\text { Aniline ... ... }\end{array}$ & $\begin{array}{c}\ldots \\
\ldots \\
\ldots \\
\ldots \\
\ldots\end{array}$ & $\begin{array}{l}0.0 \\
0.0 \\
4.2 \\
0.0 \\
0.0 \\
0.0 \\
1.7 \\
14\end{array}$ & $\begin{array}{r}0.0 \\
56.3 \\
52.2 \\
0.0 \\
5.5 \\
0.0 \\
116.8 \\
0.0\end{array}$ & $\begin{array}{r}0.0 \\
2.8 \\
16.9 \\
0.0 \\
31.8 \\
1.4 \\
8.3 \\
4.0\end{array}$ & $\begin{array}{r}0.0 \\
35.5 \\
34.8 \\
6.7 \\
9.5 \\
27.1 \\
36.8 \\
1.1\end{array}$ \\
\hline
\end{tabular}

TA BLE VIII.-Giving the Number of Paramoecia passing into Tubes of Acid and Alkali in Tables VI and VII, in Percentaye of the Number of Paramoecia passing into the Corresponding Control Tubes (containing Distilled Water in Table VI, anit Hay Infusion in Table VII). 
This is clearly seen in Table VII, and in Table VI it is also seen, though in some experiments more paramoecia pass into the tubes containing acid than into the control tubes. (Compare also Table VIII.). At first. I regarded the latter as evidence of a true positive chemiotaxis, but subsequently I found myself compelled to abandon this view, since further experiments showed that the tendency to pass into tubes containing acids in greater numbers than into control tubes was not a constant, but merely an occasional, feature of such experiments, and that if several experiments are averaged, the number of para moecia entering tubes containing acids is less than that entering the control tubes. A somewhat similar feature is exhibited in Table VII. Here it is seen that the number of paramoecia entering tubes of distilled water is in most experiments less than that entering tubes of hay infusion the former being on the average only about one quarter as numerous as the latter; but four exceptions occur, namely Experiments 1, 15, 19,31, in which the number of paramoecia entering amounted to respectively 135 per cent 108 per cent., 143 per cent., and 108 per cent. of those passing into the control tubes. A two-fold variability is inseparable from experiments on chemiotaxis: first the variability in successive experiments, partly due to change in the condition of tine paramoecia, which unfor tunately cannot be kept constant from day to day, or even from hour to hour, and partly to the next factor; secondly, variations involving the individual tubes employed in the same experiment, attributable to undetected variations in the conditions of experiment. The chance of the latter occurring is obviously greater the weaker the concentration employed; if hyper-lethal concentrations are used strong negative chemiotaxis is alone observed. The variability which is present in successive experiments places a difficulty in the way of determining the relative influence of individual acids and alkalies upon paramoecia. From the single experiments given in Tables VI and VII no conclusion can be drawn. A comparison of the chemiotaxis of acids and alkalies in equilethal concentration in respect of paramoecia in distilled water (cf. Table VIII), however, shows that the latter are more negatively chemiotactic than the former. In equi-molecular concentration this difference is no longer marked.

In all experiments on the chemiotaxis of paramoecia a difference of osmotic pressure comes into play, to which in part the phenomena of chemiotaxis are due. ${ }^{29}$ This occurs, for example, in the experiments recorded in Table VII, in which the paramoecia were immersed in hay infusion. If the paramoecia passing into the tubes containing dis tilled water are compared with those passing into acid and alkali, it is seen that the latter are less than the former for the stronger concentrations, but that the difference is inconsiderable with the weaker concentrations. In these experiments obviously difference of osmotic pressure plays a share in the taxis noted. In Table VI the difference of concentration, that is, of osmotic pressure, is greater for the stronger alkalies than for the stronger acids, and the chemiotaxis is also greater, but the difference of concentration is less than that between hay infusion and water. In practice, however, since it is as yet impossible to separate the physico-chemical from the purely chemical effect of acids and alkalies, the term chemiotaxis must be understood to include both, and whenever the composition of the fluid to be tested is stated, the characters of the liquid in which the paramoecia are contained should also be given.

The foregoing observations may be summarized as follows :

1. Paramoecia pass readily into tubes containing acid and alkaline solutions of sublethal concentration, but pass still more readily into control tubes containing the same liquid as that in which the paramoecia are immersed.

2. Only negative chemiotaxis appears to be exerted by acids and alkalies upon paramoecia This negative chemiotaxis is marked in alkaline solutions of lethal concentration, and is slighter in acid solutions of lethal concentration.

3. There is no parallelism between (a) the lethal concentration of acids and alkalies for paramoecia, and (b) the chemiotaxis of paramoecia in respect of acids and alkalies.

4. The taxis of paramoecia is modified when these organisms are transferred from hay infusion to distilled water.
5: Chemiotaxis is not to be explained simply by reference to the acidity or alkalinity of the solutions employed. Mere change of concentration is an important factor in its production.

6. Negative chemiotaxis does not necessarily indicate that the liquid tested acts injuriously upon the organisms employed.

In conclusion, I must express my indebtedness to Professor Verworn, in whose laboratory the above research was conducted ; to Professor Nernst, who kindly permitted me to make the physical measurements in the Physikochemisches Institut in Göttingen, and also to Professor Coehn, at whose suggestion palladium-hydrogen electrodes were employed.

\section{Eine Wirkung galvanischer Ströms}

Phan Organismen, Pfiiger's Protio $f$. ges. Physiol. Bd. 37, p. 457. 2 Die polare Erregung der Physiol. Bd 45 , p. 1 and Bd. 46, p. 267. 3 Untersuchungen über den

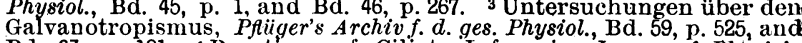
Bd. 63, p. 121. 4 Reactions of Ciliate Infusoria, Journ. of Physiol. vol. Xxi, p. 258 ; the Mechanism of the Motor Reactions of Para mecium, Amer. Journ. of Physiol., vol. ii. p. 311 ; On the Movements and Motor Reflexes of the Flageliata and Ciliata, ibid., vol. iii, p. 299 ; The Laws of Chemiotaxis in Paramecium, ibid., vol. ii, p. 355. ' 5 Zur Theorie des (alvanotropismus, Pfliiger's Archiv: $f$. d. ges Physiol.
Bd. 65, p. 525 : also (Jacques Loeb), ibid., Bd. 65, p. 308 ; also (Jacques Loeb and S. S. Maxwell), ibid., Bd. 63 , p. 121.6 Studies on Electrotaxis, Amer. Journ. of Physiol.. vol. iv, p. 96. ${ }^{7}$ Uber die Einwirkung des constanten Galvanischen Stromes auf niedere Organismen, Arch. f. Anat. u. Physiol., Physiol. Abth. Jahrg. 1900, p. 49.8 Galvanotaxis p. 291. 9 Zur Kenntnis der Galvanotaxis. Zitschrol. vol, xxv1, p. 291. ${ }^{9} \mathrm{Zur}$ Kenntnis der Galvanotaxis, 'Zeitschr. f. allg. Physiol. Coagulation of Proteid by Electricity, Journ. of Physiol., vol. xxiv, p. 288. 12 Resorption und Kataphorese, Pfiuger's Archiv f. $d$. . ges.
Physiol., Bd. 101, p. 607: Weitere Mitteilungen über Ionenpermeabilitat bei Blutkörpercheu, ibid., Bd. 102, p. 196. ${ }^{13}$ Uber Galvano taxis voul Standpunkte der Pliysikalischen Chemie, Zeitschr. f. ally. Physiol., Bd.5, p. 1. 11 Loc. cit. 15 Loc. cit. 16 The Effect of Ions upon the Aggregation of Flagellated Infusoria, Amer. Journ. of Physiol., vol. ili, p. 291. 17 Die chemische Reizbarkeit der Leukocyten und deren Beziehung zur Entzündung und Eiterung, Berl. klin. Woch. 1890, No. 47 : cf. also Ueber pyogene Stoffe in der Bakterienzelle, ibid. bienne. 30 . Le chimiotaxisme des leucocytes et l'infection micro(fixateurs) dans la phagocytose, Annales de l'Institut Posteur, T, 16 , p. 106. \&0 The Phagocytosis of Red Blood Cells., Proc. Roy. Soc. Series B, vol. 76, p. 524 . 21 The External Phenomena of Fertilizatiou, Buller, Quart. Journ. of Micro. Science, 1902, vol. xlvi, p. 115. Journ. of Physiol., vol. ii, p. 339 . 23 A brief outline of this inquiry is given in the BRITISH MEDICAL JoURNAL, 1905, vol. ii, p. 17. 24 Di absolute Kraft einer Flimmerzelle, Pflïger's Archiv f.'d. ges. Physiol. Table I; also Proc. Roy. Soc., 1904, vol. lxxiv, p. 100. 26 Die kohlenTäule I; also Proc. Roy. Soc., 1904, vol. lxxiv, p. 100. ${ }^{26}$ Die kohlen1905, Bd. 5, S. 10 vo Paramacium aurelia, Zeitschr. f. allg. Physiol. Paramäcien, Zeitschr. f. allg. Physiol. 1904 Bd 4, S. 438. 28 Eine neue Methode zur Bestimmung der Reaktion des Blutes, Pfiuger's Archiv d. ges. Physiol., Bd. 96, 1904. p. $601 .{ }_{29} 9$ Jean Massart, Sensibilité et Adaptation des Organismes a la Concentration des Solutions Salines, Archives de Biologie, 1899, T. 9, p. 515

\section{THE DIAGNOSTIC VALUE OF X RAYS.*}

\section{BY JAMES MACKENZIE DAVIDSON, M.B., C.M.ABERD.}

MEDICAL OFFICER IN CHARGE OF ROENTGEN-RAY DEPARTMENT, ROYAI, OPHTHALMIC HOSPITAL AND CHARING CROSS HOSPITAL,

Ten years have passed since $x$ rays came into use in medical and surgical work, but there are many who do not yet realize the proper way of employing them, or their necessary limitations.

In this connexion, the main point $I$ wish to urge is the importance of always taking $x$-ray photographs stereoscopically. Some slides will be thrown upon the screen to illustrate this point, as also some stereoscopic transparencies.

An $x$-ray photograph produced by a good focus tube is often so clear that it is not easy to realize that it is only a shadow of the object which was interposed between the tube and the plate, and that the apparent relative positions of the parts by no means represent the actual positions.

In the British Medical Journal of January 1st, 1898, however, I described a method of precise localization; and again, on December 3rd, 1899, I published an illustrated article on $x$-ray stereoscopy. Later I applied my method of localization to ophthalmic work, and found that the position of exceedingly minute particles of metal or glass can be determined in the eyeball or orbit to the $\frac{2}{5} \mathrm{th}$ of an inch. Several cases of this kind are reported in the Transactions of the Ophthalmological Society of the United Kingdom.

I regret that this communication is the last one on the * Read before the Section of Medicine at the Annual Meeting at 